\title{
Scrutiny of Critical Thinking Concept
}

\author{
Ali Mohammad Siahi Atabaki ${ }^{1}$, Narges Keshtiaray ${ }^{1} \&$ Mohammad H. Yarmohammadian ${ }^{1}$ \\ ${ }^{1}$ Department of Educational Sciences, Isfahan (Khorasgan) Branch, Islamic Azad University, Isfahan, Iran \\ Correspondence: Narges Keshtiaray, Department of Educational Sciences, Isfahan (Khorasgan) Branch, Islamic \\ Azad University, Isfahan, Iran. E-mail: Keshtiaray@gmail.com
}

$\begin{array}{lc}\text { Received: October 16, } 2014 & \text { Accepted: November 20, } 2014 \quad \text { Online Published: February 25, } 2015 \\ \text { doi:10.5539/ies.v8n3p93 } & \text { URL: http://dx.doi.org/10.5539/ies.v8n3p93 }\end{array}$

\begin{abstract}
Learning critical thinking skills are the goal of educational systems so the term "critical thinking" (CT) is frequently found in educational policy documents. Despite this frequency, however, precise understandings among teachers of what CT really means do not exit. The present study is designed to answer the following question. We can classify critical thinking concept in a conceptual framework. A qualitative content analysis with deductive categorization was used to classify critical thinking concept in a conceptual framework .The research field (statistical population) included all available digital and written sources related to critical thinking. The Research sample was a purposeful homogeneous sample. It is used to describe the sample that includes information based on the qualitative research goals. The results showed that critical thinking concept could be investigated in fields of both psychology and philosophy. While philosophers emphasis on the nature and quality of critical thinking, psychologists focus on cognitive process and components used to investigate the practical problems. So philosophers emphasize critical thinking attitudes while psychologists focus on critical thinking skills.
\end{abstract}

Keywords: critical thinking, educational goals, thinking skills, thinking attitudes

\section{Introduction}

Thinking is one of the most necessary aspects human lives. Everyone needs critical thinking skills to be successful in solving the problems in difficult situations and having effective and acute communication with others. Critical thinking skills help people to have critical look about society problems and, instead of undisputed imitation, try to resolve them. Everyone needs to analyze and evaluate his/her living conditions to make important decisions in his life. In recent years, educational specialists have been concern about the inability of students in critical thinking skills reference. Growing students' mental skills has always been an issue, but nowadays, it is in a critical state because our information output is more than critical thinking skills (Meyer, 2007). Thinking is the ultimate goal of training and a crucial component of educational processes. There are different approaches in education but they all agree that thinking is the final outcome of education. However, there are some voices that say "thinking in educational system is in danger" (Heidegger, 2001)

The goal of educational systems is educated people who are independent and can think effectively. Students must be educated and motivated to research. They should not follow others without any investigation (Kadivar, 2002). Learning how to think is the goal of education. It needs to educate learners who can analyze and judge demanding for jobs in global economy, democracy survival and ability to make decision on the rapid changes in society (Dewey, 1993). Although critical thinking is one of the most important concepts in 21th century, its origin belongs to Plato. Philosophers such as Socrates, Plato, and Aristotle regarded critical thinking as the ability to ask questions, test, and think about ideas and values (McConnell, 2008). There are different ideas about critical thinking because critical thinking is a complex concept and includes complex activities and mental processes that are not easy to describe and measure (Vacek, 2009).

Another reason of independent and think effectively is that each researcher defines it with regard to his own understanding and research needs. Despite an emphasis on the critical thinking issue as the goal of educational systems, there is no motivation to help students think critically and use this ability in their lives (Maleki,1386). School teachers focus on transferring information but training creative thinker is neglected (Shabani, 2004). The result of Teacher Information Management System (TIMISS) test shows the weak performance of Iranian students. The rank of Iranian students in mathematic is 39 and in science 38 among 40 countries (Jahani, 2003). 


\subsection{What Is Critical Thinking? What Are Its Features?}

A lot of philosophers and scientists tried to answer these questions. Ordinary people also welcomed critical thinking at schools. This educational perspective is generally supported in recent years and is completed by critical movement in the second half of the $20^{\text {th }}$ century (Jahani, 2003). So the present study is designed to answer the following question.

Can we classify critical thinking concept in a conceptual framework?

\subsection{Theoretical Framework}

Theoretical foundation of critical thinking can be divided into two groups:

Definition and theories based on psychology

Definition and theories based on philosophy

The lack of relationship between psychology and philosophy is the reason of having different definition (Reed, 1998).

\subsection{Definitions and Theories Based on Philosophy}

Philosophical theories are theories of logic and opinion about understanding the issues, i.e. what a person needs for thinking. Socrates related critical thinking to philosophy by his exploratory dialogues. In this way, he helped people to think about themselves and achieve their knowledge. In his opinion, critical thinking means discovering the truth. In process of Socrates' dialogue, people get an unstable and turbulent awareness of untested beliefs and assumptions. People feel depressed and chaotic in recognition of themselves. This is confusion and Knowledge of their ignorance and idiotism (Neistani, 2011).

After Socrates, Plato and then Aristotle continued their research about thinking and knowledge. Plato believed that people are discovering the knowledge while Aristotle believed that intellectual talent is one of the most important features of people. In his idea, emotional life is an introduction to intellectual growth. The contemporary reform movement in

Educational system is closely related to informal logic that was a specific field in philosophy in early 1970 . The informal logic is a branch of logic that is related to analysis, testing, and mistake investigation in language. Informal logicians consider critical thinking as a broader expression that includes informal logic findings but benefit other forms of logic (Johnson, 2007). Informal logic supports accurate theoretical foundations for critical thinking with little emphasis on the arguments and evidence. Although informal logic supported the idea of critical thinking based on philosophy, other philosophers also paid attention to critical thinking component. There are different ideas about critical thinking but we can find same issues among them (Ennis, 1985). Johnson (2007), McPeck (1981) and Paul (1993) mentioned the similarities as "Critical attitude emphasizes on complete support of reasons before accepting controversial claims, tests different functional measures for judgment, judges claims and discussions and is sensitive to possible bias."

Annis (1992) believed that critical thinking is a rational and reflexive thinking focusing on beliefs and decisions. In his idea, each person needs motivation to think critically. He classified critical thinking into five main processes: 1) Initial classification; 2) Serious supporting; 3) Conclusion; 4) Advanced classification; and 5) Strategy and method. Henri (1991) identified five dimensions in analyzing the problems: 1) Participation; 2) Community; 3) Interaction; 4) Meta cognition. Garrison (1991) believed that critical thinking includes five steps: 1) identifying the problems; 2) defining the problems clearly; 3 ) searching possible solutions; 4) evaluating their functions; and 5) integrating their understanding with available knowledge.

All of these philosophical ideas (Ennis, 1985; Garrison, 1991; Henri, 1991) put emphasis on the formal needs of thinking. Facione (1998) designed his critical thinking model according to the philosophical idea too. He wanted to know how critical thinking can be defined in different levels of university. There are six critical thinking skills in Facione's model: 1) interpretation; 2) analysis; 3) Testing; 4) inference; 5) Explanation; and 6) self regulation. Lipman (2003) believed that critical thinking is one kind of reflective thinking that helps people to judge easily and correctly. In his idea, critical thinking is related to cognitive growth and intellectual responsibility. He also believed self-correction is one of the most important features of critical thinking. In his opinion, interests and trends have important roles in critical thinking. Basic skills like reading, writing, arithmetic, and verbal communication have an important role in developing social skills but they are not enough for critical thinking.

\subsection{Definitions and Theories Based on Psychology}

While philosophers focus on the nature and quality of critical thinking as a product, psychologists emphasize 
cognitive processes, components, and applications used to examine practical problems (Reed, 1998). Critical thinking includes three components: 1) post components; 2) components of performance; and 3) components of gaining knowledge. Post components are executive components of intelligence used for designing. Components of performance help to implement the instruction of post components. They are the executive part of intelligence. Components of gaining knowledge refer to the ability of learning and using language. Therefore, they help people to use signs for solving problems and getting new information. According to these components in critical thinking, everybody has to recognize the nature of problems, try to solve it, prepare a design and test its messages and feedback (Norshima, 2011). Unlike philosophers, psychologists focus on growth, cognitive psychology, and intellectual theories (Bransford, 1998; Halpren, 1998). Psychologists try to make a relationship between critical thinking and high level skills but most of them prefer to use high skills instead of critical thinking (Strenberg, 1987; Smith, 1993).

While philosophers focus on critical thinking attitudes, psychologists put emphasis on critical thinking skills. As a result, it can be stated that the consensus of educational psychologists should challenge learners' ideas but it cannot be done without critical thinking skills. Most cognitive psychologist emphasizes testing cognitive schemata among beginners and experts in various areas. Studies done about the structure of cognitive skills show that how problem-solving process changes by increasing the knowledge and experiences but developments psychologists emphasize teaching critical thinking skills.

Literature shows what they are carried out in various eras. In the first era, researchers paid attention to logic, discussion, and reasoning as well as feeling and affection have been neglected. Reasoning and logic were sketchy in this stage so there was a rupture between formal and informal logic. Learners had a lot of problems in interpretation and understanding critical thinking when they defined it as logic and analysis. The results showed that one or two separate subjects can't change students' critical thinking and critical thinking can't be taught in a specific class properly, the second stages of researches were started. In the second stage, teaching cognitive skills of critical thinking and not memorizing the facts was important; but curriculum specialist didn't know how they could use these skills in textbooks. In this stage, they emphasize cognitive skills of psychology, so teaching critical thinking in other majors was motivated. In the third stage, researchers tried to remove the weakness of the first and the second era. In the first stage, researches used empirical studies and the content of logic; in the second stage, they focused on empirical skills and studies; however, critical thinking tendencies were the outcome of the third stage. Elements such as ethical reasoning, emotion, insight, value, and emotional areas were important in the third stage (Naseri, 2011).

\section{Literature Review}

Reference to critical thinking can be found in the early 1900s, when Dewey (1910) wrote about thinking. Dewey stated that "the essence of critical thinking is suspended judgment" (p. 74). His emphasis on critical thinking was prevention of conclusions until a problem is completely understood. Dewey offered an example of a physician diagnosing a patient. If a physician listening to a patient, describing symptoms, stops the patient as soon as he hears symptoms that suggest a disease, the physician may miss critical information that suggests a different diagnosis. Philley (2005) called this type of thinking (i.e., going beyond the obvious conclusion and searching for alternate explanations) lateral thinking (p. 27) and emphasized its importance in incident investigation. Dewey (1910) suggested that deduction and induction are the primary components of critical thinking. Induction is used to move from detailed facts to general principles. Deduction is used to test the hypotheses developed through induction, confirming the conclusion. In other words, Dewey likened critical thinking to the application of logic for analyzing information. For example, sitting in the student union and watching the number of students using cell phones, one may hypothesize that all college students have cell phones. This example is an application of inductive reasoning. To test this hypothesis, a class of students could be asked to raise their hands if they have a cell phone. Testing this sample of students is an example of deduction.

Fifty years later, Smith (1959) tested this concept by conducting research to determine if teaching logic in various courses improved students' critical thinking skills. The results of his study did not support the theory that teaching logic is the same as teaching critical thinking. Smith speculated that unidentified factors hindered the students' understanding of logic which prevented them from developing critical thinking skills. Later, research reviewed some key aspects of these other factors. Ennis and Paulus (1965) began with Smith's concept of critical thinking. However, Ennis did not accept the premise that deductive logic provided a complete description of critical thinking. Ennis went beyond this simple definition and developed a list of attributes of a critical thinker. Some of these characteristics included the ability to recognize (a) a conclusion that follows an assertion, (b) a generalization that is appropriate, and (c) facts versus assumptions. Later, Ennis (1985) defined critical thinking as "reflective and reasonable thinking that is focused on deciding what to believe or do" (p. 45).Ennis proceeded 
to evaluate the top three levels (analysis, synthesis, and evaluation) of Bloom's taxonomy (Bloom, Engelhart, Furst, Walker, \& Krathwohl, 1956) as a possible description of critical thinking. Ennis maintained that Bloom's taxonomy was not specific enough to be useful for guiding the teaching of critical thinking skills. To address this limitation, Ennis listed 13 dispositions and 12 abilities of a critical thinker (p. 46).

Bloom et al. (1956) presented a number of abilities and skills undereach of their taxonomy levels. For example, under analysis, they listed "the ability to recognize unstated assumptions" and "skill in distinguishing facts from hypotheses" (p. 205). Ennis's (1985) listed abilities were remarkably similar: Ability 10 was "identifying assumptions" and ability $7 \mathrm{~b}$ was" inferring explanatory conclusions and hypotheses" (p. 46). Although Ennis minimized the significance of Bloom's taxonomy for guiding teachers, these two sets of abilities shared a variety of characteristics. Another theorist, McPeck (1981), described critical thinking as "the appropriate use of reflective skepticism within the problem area under consideration" (p. 7). He considered logic to be a relatively limited aspect of critical thinking. McPeck was criticized by other theorists for his view that critical thinking is not transferable; that is to say, a person with critical thinking skills in one field, such as mathematics, cannot necessarily apply those skills to think critically in another field, such as psychology. McPeck (1990) based his discipline-specific argument on what he considered to be common sense. His first point was that general thinking does not exist; when people think, they are always thinking about something specific. Second, McPeck noted that some people have effective thinking skills in one or more fields, whereas other people have thinking skills in other fields. For example, a person would probably not seek medical advice from a financial analyst, no matter how bright the analyst might be. Finally, McPeck noted that pertinent knowledge is an important element of critical thinking. Thus, a thinking skill without the specialized knowledge of the discipline is meaningless.

Despite these arguments, most theorists appear to support the notion of transferability. Halpern (1998) emphasized the transferability of critical thinking skills, defined as "the use of those cognitive skills or strategies that increase the probability of a desirable outcome" (p. 450). One of the four skills Halpern recommended teaching to improve critical thinking was developing transfer. This emphasis on transferability demonstrates her support for the concept.

The transferability argument appears to be less about whether critical thinking skills are transferable and more about how much of the skill is transferable. Although McPeck (1990) argued against the transferability of critical thinking, he acknowledged certain common qualities of all critical thinkers such as reflective skepticism. In contrast, Halpern (1998) contended that her four-part critical thinking teaching model (described later) is common to any field. The question of transferability is important to the discussion of how critical thinking skills should be taught. For example, if critical thinking skills are not transferable, students cannot be expected to gain much from a critical thinking course. Paul and Elder (2002) described critical thinking as a meta cognitive skill. They defined critical thinking as "that mode of thinking — about any subject, content, or problem —in which the thinker improves the quality of his or her thinking by skillfully taking charge of the structures inherent in thinking and imposing intellectual standards upon them" (p. 15). In other words, critical thinkers are continually analyzing and evaluating their own thinking (Paul, 2005). This process is used to think about information in a way that will allow the thinker to arrive at a better conclusion.

Spelton (2011) did a research about teachers' critical thinking skills. The result of the research showed that although critical thinking is a part of curriculum in Hong Kong, most teachers in high schools are not familiar with critical thinking skills and methods of teaching it. Hove (2011) did a research about the development of critical thinking in high schools. Investigating the effect of teaching critical thinking strategies on students thinking skills was the goal of the research. Findings showed that performance of those students who were taught by critical thinking strategies were better than the others.

Noshadi (2011) evaluated social studies curriculum. He used the critical thinking skills and critical thinking tendencies scales based on Facione's model to analyze the textbook of the Social Studies major. Findings showed that teachers and students in teacher training centers of Iran were weak in critical thinking skills and attitudes. Soleimannezhad (2012) conducted a research about the relationship between psychological beliefs and students' critical thinking tendencies. California critical thinking questionnaire was used to gather the data. Findings showed that there is a meaningful relationship between psychological beliefs and students' critical thinking attitudes. 
Summary of critical thinking definitions

\begin{tabular}{|l|l|}
\hline Experts & Definitions \\
\hline Socrates & Reasoning debate or process of critical questions \\
\hline Dewey & Ongoing review of ideas and beliefs and reasoning defeat them \\
\hline Smith & Creating, application and using concepts \\
\hline Rajiro & Growth of logical reasoning skills \\
\hline Kant & $\begin{array}{l}\text { Liberal thinking, knowledge and responsibility for making decision with regard to the measure } \\
\text { of performance }\end{array}$ \\
\hline Strenberg & Problem solving and making decision \\
\hline Skerun & Searching the hypothesis \\
\hline Ketinjer & The application of constructive judgment \\
\hline Paul & Overcome bias, fanaticism and stereotypical thinking \\
\hline MacPeck & Reflexive suspicion \\
\hline Onill & Ability to recognize bias from facts and dividing reasons according to ideas \\
\hline Halpren & Targeted thinking for making decision, interpretation, or solving the problems \\
\hline Beyer & Discrimination between valid facts and claims \\
\hline Lipman & $\begin{array}{l}\text { Thinking based on skills and responsibilities that cause fast judgment. It is based on criteria and } \\
\text { sensitive to fields. }\end{array}$ \\
\hline Ennis & Correct evaluation of ideas and reflexive thinking about what we believe and what we do \\
\hline Facione & Ability to discuss and evaluate \\
\hline
\end{tabular}

\section{Research Method}

This research was a qualitative one. A qualitative content analysis with deductive categorization was used to classify critical thinking concepts in a conceptual framework. Content analysis is a way to analyze the information and is useful for media products, interviews, written sources, and so on. Using categories from theoretical models is one of the most important points of this method (Uwe, 2006). The research field (statistical population) includes all available digital and written sources related to critical thinking. The research sample is a purposeful homogeneous sample. It is used to describe the sample that includes information based on the qualitative research goals. Ideal way in this case is to reach saturation (the case that does not have any new information). In qualitative research, selecting the sample is directly related to researchers' decision. Therefore, there is not any fixed rule for it. The volume of sample requires a barter deal between the study and its depth (Gall, 2003).

Gathering the data from available digital and written sources was done by exploring summaries of the related books and sources. Analyzing the data was done by deductive categorization system and it gave code to subjects. Formulation of defined criteria is the main point in this method taken from review literature and research question parts. Analyzing the data and eliciting different categories were done step by step.

Giving Codes to the subjects was done in three steps:

Open coding: The goal of open coding is to change words and phenomenon to concepts. So at first data is divided, words and clauses are classified according to their meaning then some code are given to them (Uwe, 2006).

In this research available digital written sources were studied carefully and then concepts were elicited and coded. After that codes were classified according to discovered concepts of data.

Axial coding: In this step, categories taken from open coding are defined and split. Categories that seem to be more useful for the next step are selected from pervious steps and put in one group. Axial coding is the process of relating more important categories and includes the complex processes of deductive and inductive thinking done during several steps by comparing and asking questions (Uwe, 2006).

Selective coding: In this step, axial coding was in more abstract level and each category was tagged. 


\subsection{Validity and Reliability of Research}

In order to have valid findings, after analyzing data, they were given to critical thinking specialists then they were reviewed and corrected according to their opinions.

Reliability in qualitative research refers to the trustfulness of data and being accurate in complementation of research. Therefore, in order to have reliable findings, the researchers tried to study the subject very carefully and elicit the related and important paragraphs then studied them again.

\section{Findings of Research}

Can we classify critical thinking concept in a conceptual framework?

In order to answer the research question all available digital and written sources about critical thinking were studied and then related paragraph of the research question were elicited, coded and classified. Then the main concepts were elicited.

Results show that the concept of CR should be investigated in both fields of psychology and philosophy. While philosophers emphasis on the nature and quality of critical thinking, psychologists focus on cognitive process and components used to investigate the practical problems. Philosophers emphasis on critical thinking attitudes but psychologists focus on critical thinking skills.

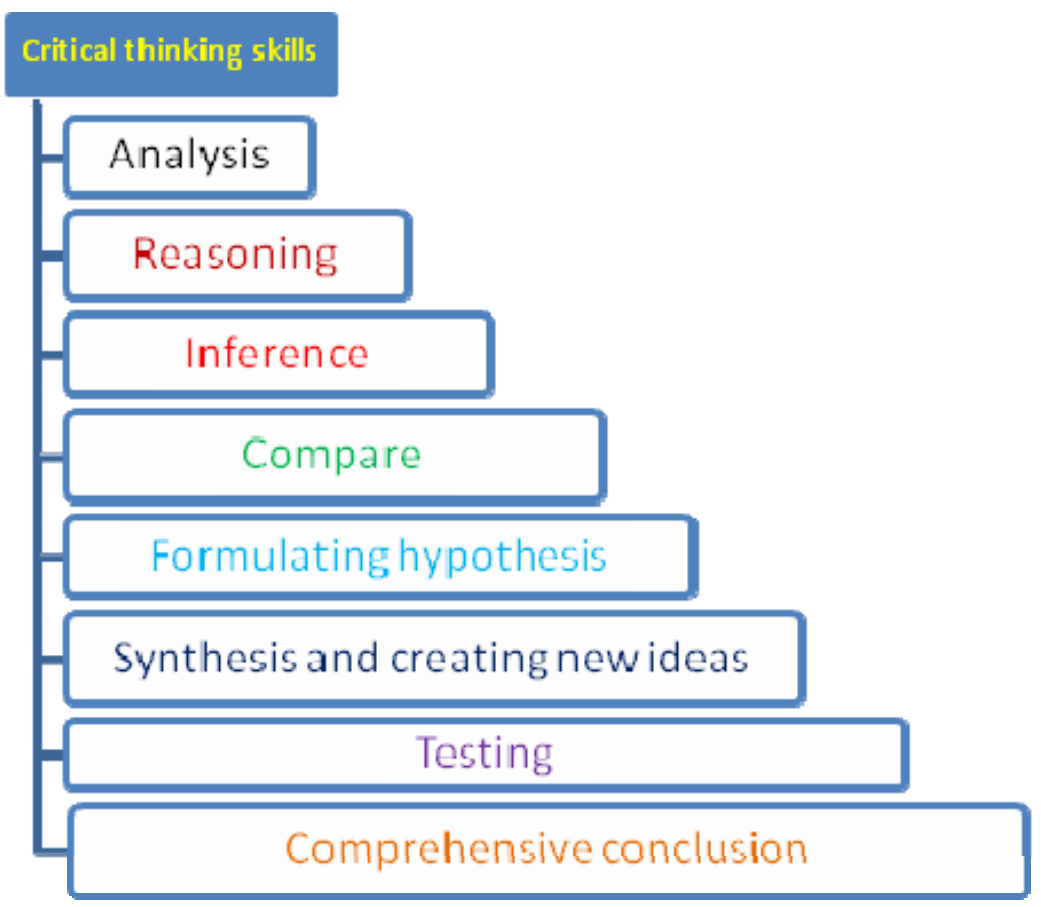

Figure 1. Critical thinking skills 


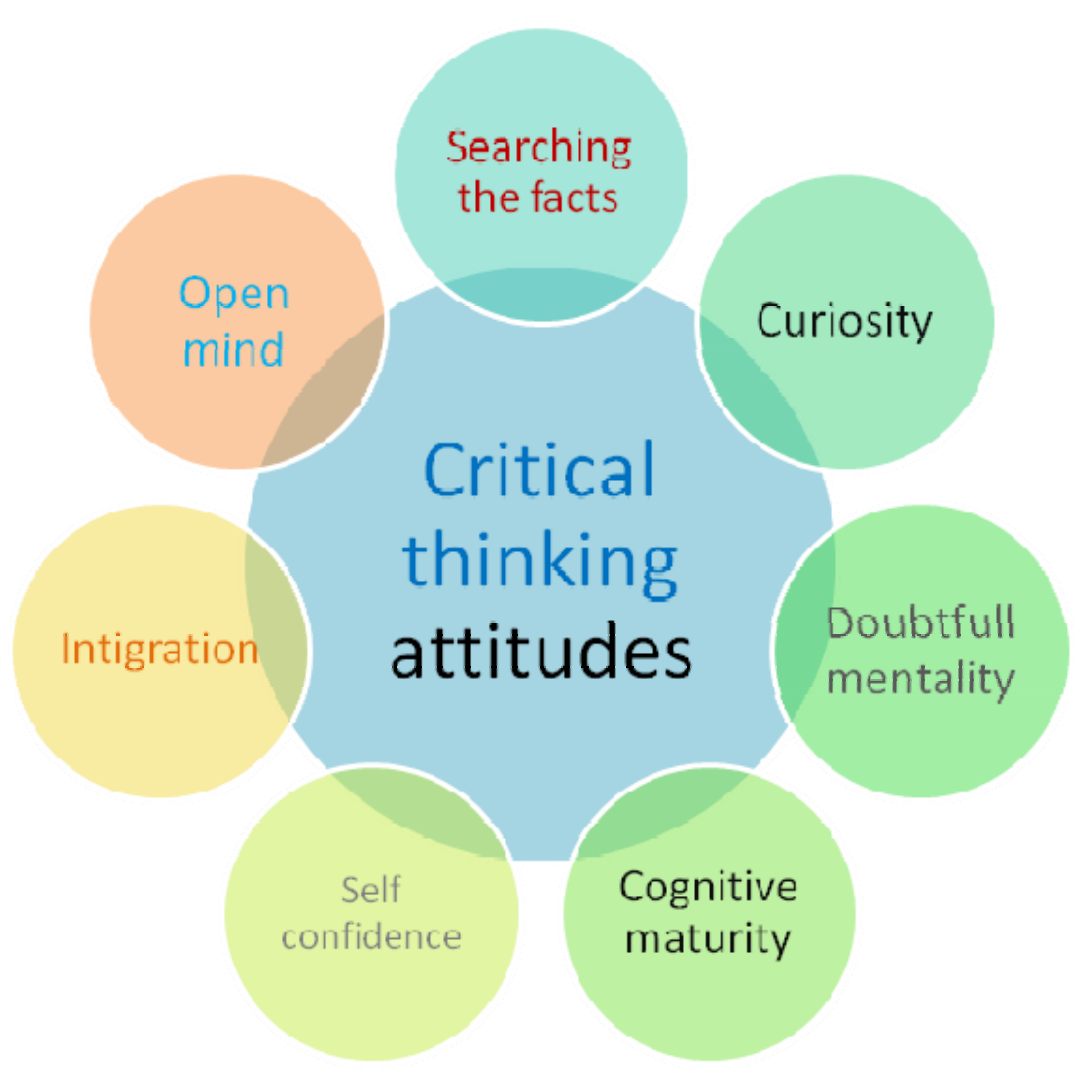

Figure 2. Critical thinking attitudes

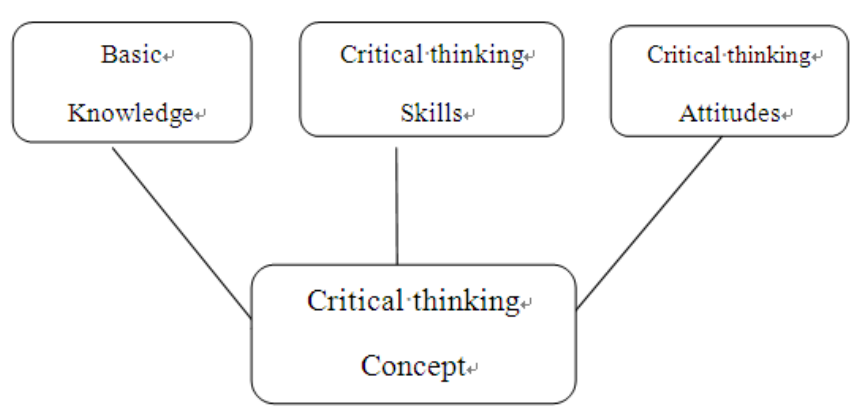

Figure 3. Critical thinking concept

\section{Conclusions}

The main question of the research is "Can we classify critical thinking concept in a conceptual frame work?"

Findings show that each researcher has defined critical thinking according to his own ideas so it can be mentioned that the number of critical thinking definitions are equal to the number of scholars in this field. In order to classify critical thinking concept in a conceptual framework specialist' opinions about critical thinking should be investigated in two fields of psychology and philosophy. Logic and ideas are used more in philosophy in other words what a person needs to think. Therefore, in this field, critical thinking attitudes are more important. They are searching for facts, open minds, integration, self-confidence, curiosity, and a doubtful mentality.

Searching for facts: being interested in getting the facts and brave to ask questions. These kinds of people are more interested in revealing the facts than emphasizing on their ideas. Therefore, they always try to investigate different ideas and evidences to get the facts. Searching the facts includes components such as being interested in inquiry and correcting the ideas, having responsibility for selecting and using criteria, having flexibility in investigating the ideas and different solutions, having the ability to think about mistakes and evaluating the 
problems.

Open minds: investigating different ideas, tolerating divergent opinions, and respecting others' ideas. An open mind includes components such as understanding other people's opinions, paying attention to divergent ideas, being honest, and having no prejudice.

Integration: trying to be regular in everything. Integration includes components such as asking questions regularly, having perseverance in searching information, and concentrating on the information.

Self-confidence: trusting oneself in solving the problems and judging them.

Curiosity: means that people are always interested in knowing different things and value their awareness.

Cognitive maturity: means that people are very careful in their judgments and try to judge according to standards. Cognitive maturity includes components such as being careful in judgment or suspending it and having a logical mind in evaluating information.

Doubtful mentality: means that people take different affairs with suspicion and does not suppose anything as definitive.

Findings in this part of research coordinate with findings in following researches: Ennis (1986), Facione (2010), Garrison (1991), Johnson (1996), Naseri (2011), and Paul (1985). Unlike philosophers, psychologists emphasize growth, cognitive, and intelligence theories. They try to make relationship between critical thinking, problem solving, and high levels of thinking skills. Therefore, they focus on critical thinking skills. These skills are analysis, inference, reasoning, comparison, formulating hypothesis, synthesis and creating new ideas, testing and comprehensive conclusion.

Analysis: It has a dual meaning: 1- Expressing meaning and emphasizing experiences, situations, information, events, ideas, and criteria. It includes components such as classification, recoding, and clarity of meaning; 2Recognizing a real interpretive relationship among the statements, questions, concepts, descriptions, judgments, experiments, reasons, information, and ideas. It includes components such as testing ideas, investigation, and analysis of discussions.

Inference: recognizing and keeping needed ingredients to have reasonable results instead of assumptions, guessing, investigation of related information and consequences of information, statements, principles, evidences, judgments, beliefs, ideas, concepts, explanations and questions. Inference includes components such as searching the evidence, guessing the solutions, investigating of the results, and understanding the relationship between things.

Reasoning: It includes inductive reasoning and deductive reasoning.

Comparison: observing all components of the problems, discrimination between facts and claims, and considering the various angles of problems.

Formulating the hypothesis: It includes components such as allocating time to hypothesis formation, recognizing the hypothesis and its validity and selecting possible and suitable hypotheses.

Synthesizing and creating new ideas: It includes components such as creating different methods, developing his own ideas and producing suitable solutions.

Testing: It has a dual meaning: 1-measuring the validity of statements that shows people's understanding, experiences, judgments, situations, beliefs, and ideas. In addition, measuring logical ability of real inference relationships that has no components such as testing claims, reasons and recognizing bias; 2-Stating the results of reasoning to vindicate reasoning has conceptual, methodological components or not. It includes components such as stating the result, showing the reasons, and measuring the validity of statements.

Comprehensive conclusion: It includes components such as understanding the situations completely, having perseverance to reach the results, correcting decisions, reaching to logical conclusions, and showing the valid conclusions.

Findings in this part of research are in line with findings in the some previous research like: Bransford (1987), Facione (2010), Halpren (1998), Naseri (2011), Smith (1993), and Strenberg (1987).

\section{Limitations and Recommendations for Future Research}

Low speed of internet, lack of adequate access to scientific cites and lack of a suitable and powerful software for analyzing the qualitative data were the main limitations of the research.

According to the findings of the research we present two recommendations. 
It is so important for educational specialists to provide suitable situations for increasing critical thinking skills and attitudes at schools.

It is crucial to study more about different approaches of teaching critical thinking at schools.

\section{References}

Beyer, B. K. (1985). Teaching critical thinking. A direct approach. Social Education, 49(4), 297-303.

Bloom, B. S., Engelhar, M. D., First, E. J., Walker, H. H., \& Krathwohl, D. R. (1956). Taxonomy of educational objectives: The classification of educational goals. New York: David McKay Co.

Bransford, J. (1987). How people learn. Brain, mind, experience and school. Washington DC: National Acamedy Press.

Dewey, J. (1993). How we think. Boston: D. C: Buffalo.

Ennis, R. (1992). Critical thinking: What is it? Proceedings of the 48th annual meeting of the Philosophy of Education Society. Retrieved from http://www.ed.uiuc.edu/PES/92_docs/Ennis.HTM

Ennis, R. H. (1985a). A logical basis for measuring critical thinking skills. Educational Leadership, 2(43), 2.

Facione, P. A., Facione, N. C., \& Giancarlo, C. A. (1998). The disposition toward critical thinking: Its character, measurement, and relationship to critical thinking skill. Informal Logic, 20(1), 61-84. Retrieved from June 12, 2009, from http://www.insight assessment.com/9articles2.html

Gall, M. (2011). Educational research. Tehran: Beheshti University.

Garrison, D. (1991). Critical thinking and adualt education.

Halpren, D. F. (1998). Teaching critical thinking for transfer acrossDomains (Vol. 53). American Psychologist.

Heidegger, M. (2001). Dicourse on thinking. Harper and row. New York.

Hove, G. (2011). Developing critical thinking. Educational technology, 10(3).

Jahani, J. (2003). An introduction to searching method of crithical thinking. Shiraz: Malek Soleiman.

Johnson, B., Steven, J. J., \& Zvoch, K. (2007). Teachers' perceptions of school climate: A validity study of scores from the revised School Level Environment Questionnaire. Educational and Psychological Measurement, 67(5), 833-844. http://dx.doi.org/10.1177/0013164406299102

Kadivar, P. (2002). Educational psychology. Tehran: Samt.

Kant, E. (1981a). Assessment of the unique knowldge (A. Soltani, Trans.). Tehran: Amirkabir.

Lipman, M. (2003). Thinking in education (2nd ed.). NewYork, NY: Cambridge university press. http://dx.doi.org/10.1017/CBO9780511840272

Maleki, H. (2007). Curriculum. Tehran: Payam Andisheh.

McConnell, J. (2008). An educational strategy to improve graduate nurses critical thinking skills during the hospital orientation program. The jornal of continuing education in nersing, 3, 193.

McPeck, J. E. (1981). Critical thinking and education. New York: St. Martin's Press.

McPeck, J. E. (1990). Teaching critical thinking. New York:Routledge.

Meyer, C. (2007). Teaching English (K. Abili, Trans.). Tehran: Samt.

Neistani, M. (2011). Critical Thinking. Isfahan: University.

Norshima, B. (2011). Critical thinking in E-learning environments. Portland State University: Center for Science Education.

Noushadi, N. (2011). Evaluation of critical thinking in social studies text book (Phd thesis, Shiraz university, Shiraz).

Paul, R. (1993). Crirical thinking and critical persons. Progress in research and teaching. Los Angeles, CA: Pekins and sons.

Paul, R. (2005). The state of critical thinking today (Vol. 5).

Paul, R. W., \& Elder, L. (2002). Critical thinking: Tools for taking charge of your professional and personal life. Upper Saddle River, NJ: Pearson Education, Inc.

Paulus, R. H. E. D. (1965). Deductive reasoning in adolescence-critical thinking readiness in grades 1-12, 
phase 1 (Rep. No.CRP-1680). State University of New York, College of Agriculture at Cornell University.

Philley, J. (2005). Critical thinking concepts. Professional Safety, 50(30), 26-32.

Reed, H. J. (1998). Effect of a model for critical thinking on student achievement in primary source document analysis and interpretation, argumentative reasoning, critical thinking dispositions, and history content in a community college history course. Retrieved from Dissertations \& Theses: Full Text database (AAT 9911510).

Shabani, H. (2004). Developed teaching methodology. Tehran: Samt.

Smith, B. O. (1993). A study of the logic of teaching. A report on the first phase of a five-year research project-the logical structure of teaching and the development of critical thinking (Rep. No. CRP-258-7257). Bureau of Educational Research.

Soleimannezhad, A. (2012). Investigating the relationship of psychological belief and critical thinking tendency of high school students. Tehran: Sanmt.

Spelton, A. (2011). Teachers' critical thinking skills. Teachers' critical thinking skills: Gazi University, Turkey.

Strenberg, R. J. (1987). Teaching intelligence: The application of cognitive psychology to improvement of intellectual skills. New York: W. H. Freeman.

Uwe, F. (2006). An introduction to qualitative reseach (H. Jalili, Trans.). Tehran: Nei.

Vacek, E. (2009). Using a conceptual approach with concept mapping to promote critical thinking. Educatinanl Innovation, 1, 48.

\section{Copyrights}

Copyright for this article is retained by the author(s), with first publication rights granted to the journal.

This is an open-access article distributed under the terms and conditions of the Creative Commons Attribution license (http://creativecommons.org/licenses/by/3.0/). 